\title{
CITIZENS UNITED AND THE SCOPE OF PROFESSOR TEACHOUT'S ANTI-CORRUPTION PRINCIPLE
}

\author{
Seth Barrett Tillman ${ }^{*}$
}

Actually stable laws require a stable vocabulary .... Thus the magistrates of a state have a duty to see that names are not irresponsibly changed.

—Richard M. Weaver, Ideas Have Consequences (1948) ${ }^{* *}$

The Constitution was intended to provide structural encouragements to keep the logic and language of society as a whole from becoming corrupt, representing a technical and moral response to what they saw as a technical and moral problem.

-Zephyr Teachout, The Anti-Corruption Principle (2009)

\section{Why ThIS COLLOQUY?}

The test of great scholarship is whether it changes the way people think and the way people live. That is also true for legal academic scholarship. But, for legal academics, perhaps the greatest sign of scholarly achievement is judicial reliance upon our craftsmanship. By any measure, Professor Teachout's 2009 Cornell Law Review publication, The Anti-Corruption Principle, ${ }^{1}$ is a success. In 2010, one short year after publication, The AntiCorruption Principle was relied upon by Justice Stevens in his Citizens United v. Federal Elections Commission dissent, ${ }^{2}$ just as it was cited, disapprovingly, by Justice Scalia in his concurrence. ${ }^{3}$ If that was not enough of an accomplishment, The Anti-Corruption Principle has also been cited in

* Lecturer of Law, National University of Ireland Maynooth. Preferred Citation Format: Seth Barrett Tillman, Citizens United and the Scope of Professor Teachout's Anti-Corruption Principle, 107 Nw. U. L. Rev. ColloQuY 1 (2012). I thank: Professors Robert W. Bennett, Aaron-Andrew P. Bruhl, David M. Driesen, Brian C. Kalt, Gary S. Lawson, John Manning, and Robert G. Natelson; Roy E. Brownell II, Esq.; D. Fitzmaurice, S.P. Hickey; and the expert student-editors at Northwestern University Law Review Colloquy. All errors remain mine.

** Richard M. WeAver, IdeAs Have CONSEQuenCES 168 (1948) (emphasis added).

*** Teachout, infra note 1, at 352 (emphasis added).

1 Zephyr Teachout, The Anti-Corruption Principle, 94 CoRnEll L. REV. 341 (2009) (link).

2 See Citizens United v. FEC, 130 S. Ct. 876, 948 n.51, 963-4 (2010) (Stevens, J., concurring in part and dissenting in part) (link); $c f$. W. Tradition P'ship, Inc. v. Att'y Gen., 271 P.3d 1, ๆ 131 (Mont. 2011) (Nelson, J., dissenting) (citing Teachout) (link).

${ }^{3}$ See Citizens United, 130 S. Ct. at 928 (Scalia, J., concurring). 
practitioners' Supreme Court briefs, in other federal and state appellate and trial court briefs, and in more than thirty academic articles. ${ }^{4}$ Finally, The Anti-Corruption Principle has entered the public discourse: George Will excoriated Teachout's article in his nationally syndicated column. ${ }^{5}$ Now that is an achievement.

Teachout's The Anti-Corruption Principle is part-and-parcel of the originalist project. ${ }^{6}$ It is an attempt to understand the Constitution in light of its text, drafting records, ratification debates, and general late eighteenthcentury history. Specifically, Teachout makes three related and sequential historical and interpretive claims.

Step One. The Framers were "obsessed" with corruption. In other words, preventing or, at least, minimizing corruption was among the Framers' primary goals. ${ }^{8}$ Absent an appreciation of this purpose, one cannot understand either the Constitution's global architecture or several of its key structural provisions. ${ }^{9}$

Step Two. These separate individual anti-corruption constitutional provisions, working together, give rise to a free-standing structural anticorruption principle (“ACP”). ${ }^{10}$

\footnotetext{
${ }^{4}$ A full list of legal citations (including practitioners' briefs) to The Anti-Corruption Principle can be found by running Westlaw's Keycite ${ }^{\mathrm{TM}}$ on Teachout's article.

5 See George F. Will, Op-Ed, End Run on Free Speech, WASH. Post, May 24, 2009, http://tinyurl.com/pncntk (link).

6 Indeed, Teachout's Essay extends the work of Professors Steven G. Calabresi and Joan L. Larsen, who have sought to characterize the Incompatibility Clause as an anti-conflicts-of-interest provision, as opposed to a mere separation of powers provision. See Steven G. Calabresi \& Joan L. Larsen, One Person, One Office: Separation of Powers or Separation of Personnel?, 79 CORNELL L. REV. 1045 (1994) (link).

7 Teachout, supra note 1, at 405 (“The Framers' obsession with, and understanding of, political corruption makes sense of constitutional phrases like 'of any kind whatever' in the [Foreign] Emoluments Clause ...." (emphasis added)); see also id. at 347, 348, 351 n.45, 352, 373, 393 n.245, 404, 406 (reiterating the Framers' or the Founders' obsession with political corruption).

8 See, e.g., Teachout, supra note 1, at 347 ("[T] he fight against corruption is a central part of the United States Constitution - its historical origins, the language of the debates around it, its substance and its structure. It is not an overstatement to say that, above all else, the Framers of the Constitution saw the document as a structure to fight corruption." (emphasis added)); see also, e.g., Zephyr Teachout, The Historical Roots of Citizens United v. FEC: How Anarchists and Academics Accidentally Created Corporate Speech Rights, 5 HARV. L. \& POL'Y REV. 163, 165 (2011) (“At the time the Constitution was drafted, fighting corruption was at the core of the drafters' vision for the constitutive principles of the country.") (link).

9 See, e.g., Teachout, supra note 1, at 359 ("Ultimately, three of the biggest protections [against corruption] created by the Framers were the Ineligibility Clause, the Emoluments Clause, and the Foreign Gifts Clause."). The Ineligibility Clause and the Emoluments Clause are the same clause. It appears that the third clause Teachout meant to list was the Incompatibility Clause.

10 See id. at 342 ("The Constitution carries within it an anti-corruption principle, much like the separation-of-powers principle, or federalism. It is a freestanding principle embedded in the Constitution's structure ... . Corruption has been part of our constitutional dialogue since the beginning...."); id. at 410 .
} 
Step Three. The ACP can compete against other constitutional provisions and doctrines, thereby providing originalist foundations for upholding congressional enactments which would otherwise be struck down under competing principles. ${ }^{11}$

For example, Teachout points to the Foreign Emoluments Clause, which provides: "[N]o Person holding any Office of Profit or Trust under them [i.e., the United States], shall, without the Consent of the Congress, accept of any present, Emolument, Office, or Title, of any kind whatever, from any King, Prince, or foreign State." 12 Teachout suggests that foreign governments ${ }^{13}$ lacking loyalties to the United States may be analogized to wealthy corporations, whose "legal loyalties necessarily exclude patriotism." ${ }^{14}$ Just as Congress under the Foreign Emoluments Clause may proscribe certain federal officers from accepting gifts from foreign governments, Teachout suggests that Congress may also have a concomitant power under the ACP to proscribe corporate election campaign contributions and spending. The stakes here are quite high: If Teachout is correct, then much First Amendment doctrine and election-law jurisprudence will have to give way (or, at least, be seriously reexamined) in light of the newly discovered (or rediscovered) principle of constitutional interpretation. Indeed, Justice Stevens, and the three dissenters who joined him, used Citizens United as just such an occasion: The dissent sought to recast First Amendment jurisprudence in light of a competing constitutional visionthe Framers' anti-corruption principle.

Other commentators have criticized Teachout in regard to the second ${ }^{15}$ and third ${ }^{16}$ steps of her analysis. My critique, by contrast, will largely focus on the first step of Teachout's sequential analysis - the initial historical and textual claims. In Part II of this Essay, I argue that Teachout's historical claim is simply wrong; the Founders were not "obsessed" with corruption. Part III discusses how Teachout misunderstands the constitutional text giving rise to her purported free-standing anti-corruption principle. Even if one concedes (as, in fact, I do) the existence of a free-standing anti-corruption principle, the scope of that principle extends exclusively to appointed federal offices, not to state or federal elected positions. Thus, Teachout's ACP

\footnotetext{
11 See id. at 342, 410-11.

12 U.S. CONST. art. I, § 9, cl. 8 (emphasis added) (link).

13 Teachout actually refers to "wealthy foreigners," Teachout, supra note 1 , at 411 , and to "foreign powers and individuals," id. at 393 n.245. Teachout's usage here is somewhat strange; for Teachout's Foreign Emoluments Clause-reliant analogy to work, she must analogize corporations with foreign governments, wealthy or not. Given the government-focused language of the Foreign Emoluments Clause, wealthy individual foreigners simply will not do.

14 Id. at 393 n.245.

15 See, e.g., Gary Lawson, The Constitution's Congress, 89 B.U. L. REV. 399, 403 n.29 (2009) (link).

16 See, e.g., Toni M. Massaro, Foreign Nationals, Electoral Spending, and the First Amendment, 34 HARV. J.L. \& PUB. POL'Y 663, 694 (2011) (link).
} 
cannot inform our First Amendment analysis in regard to congressional power over state or federal election processes. Finally, Part IV of this Essay explores what is left of Teachout's ACP; how a more text-sensitive and limited ACP nevertheless has substantial implications for other areas of constitutional law, i.e., areas beyond election law. Indeed, a more text-sensitive $\mathrm{ACP}$ and the implications which flow from it are consistent with much of the new scholarship of the last decade. However, this new text-sensitive view still remains in deep tension with the prevailing academic consensus connected with the writings of Professors Akhil Reed Amar and Vikram David Amar.

\section{THE FOUNDERS WERE NOT “OBSESSED” WITH CORRUPTION}

From what quarter can the danger proceed? Are we afraid of foreign gold? If foreign gold could so easily corrupt our federal rulers, and enable them to ensnare and betray their constituents, how has it happened that we are at this time a free and independent nation? ... [Y] et we know by happy experience that the public trust was not betrayed [by the Articles Congress]; nor has the purity of our public councils in this particular ever suffered even from the whispers of calumny.

— James Madison, Federalist No. 55 (1788) ${ }^{17}$

Teachout states more than ten times that the Framers or Founders were "obsessed" with corruption. ${ }^{18}$ She is partly correct: corruption was a concern of the delegates who attended the Philadelphia Convention. But, Teachout's "obsession" language, which was uncritically adopted by the four-member Supreme Court dissent in Citizens United, ${ }^{19}$ is misplaced. Why? To make her argument, Teachout primarily looks to three constitutional provisions ${ }^{20}$ : the Incompatibility Clause, ${ }^{21}$ the Ineligibility Clause, ${ }^{22}$ and the Foreign Emoluments Clause. Here, I focus on the Foreign Emoluments Clause; how its drafting history is inconsistent with Teachout's “ob-

17 The Federalist No. 55, at 342 (James Madison) (Clinton Rossiter ed., 1961).

18 See supra note 7 (citing Teachout's "obsession" claim).

19 Citizens United v. FEC, 130 S. Ct. 876, 948 n.51, 963-64 (2010) (Stevens, J., concurring in part and dissenting in part) (quoting Teachout's "obsession" claim and citing the Foreign Emoluments Clause) (link).

${ }^{20}$ See supra note 9.

21 See U.S. CONST. art. I, § 6, cl. 2 (“[N]o Person holding any Office under the United States, shall be a Member of either House during his Continuance in Office." (emphasis added)) (link).

22 See id. ("No Senator or Representative shall, during the Time for which he was elected, be appointed to any civil Office under the Authority of the United States, which shall have been created, or the Emoluments whereof shall have been encreased during such time ...." (emphasis added)). The italicized language is unique to this clause. 
session" claim, and why its original public meaning cannot support an ACP reaching independent expenditures. I return to discussion of the Incompatibility Clause and the Ineligibility Clause in Part IV.

\section{A. Teachout's State Offices Problem}

The Foreign Emoluments Clause had a predecessor in the Articles of Confederation. Article VI of the Articles provided: "[N]or shall any person holding any office of profit or trust under the United States, or any of them [i.e., any State], accept any present, emolument, office or title of any kind whatever from any King, Prince or foreign State...." ${ }^{23}$ Although Article VI of the Articles is similar to the 1787 Constitution's Foreign Emoluments Clause, the two provisions are not identical. First, the earlier confederation provision precluded holders of "office... under the United States" and holders of "office ... under ... any ... [State]" from accepting gifts from foreign governments. By contrast, the Foreign Emoluments Clause of 1787 only restricts those holding an Office . . under [the United States] from accepting gifts from foreign governments. Second, the Article VI provision, on its face, appears to be a mandatory provision not subject to congressional control or waiver. $^{24}$ By contrast, the Foreign Emoluments Clause expressly permits federal officers to accept foreign government gifts if Congress consents.

Simply put, if the Framers had been "obsessed" by the potential for foreign corruption, they would have made use of the more expansive language from the already extant Article VI of the Articles. They did not. Instead, the modern clause represents a reform and a significant relaxation of the strictures of the older clause. Article VI precluded officers . . under any State from receiving gifts from foreign governments, not so the modern Foreign Emoluments Clause. Moreover, the Foreign Emoluments Clause's exclusion of state officials from its scope is no small thing; in 1787 (and, to some lesser extent, today) state officials had (and have) significant powers over the federal government. For example, state legislatures had the power to directly choose federal electors - a few legislatures exercised that power-and state legislatures chose United States Senators (state governors now exercise a similar power, subject to state law, in the event of a Senate vacancy). State legislatures call Article V national conventions, and state legislatures ratify proposed federal constitutional amendments, when that power is not vested in state conventions.

Given that the Constitution of 1787 liberalized the foreign government gift-giving regime in regard to state offices, and the importance of those

23 ARTICLES OF CONFEDERATION of 1781, art. VI, para. 1 (emphasis added) (link).

24 But see Applicability of Emoluments Clause to Employment of Government Employees by Foreign Public Universities, 18 Op. O.L.C. 13, 16 n.4 (1994) (Assistant Attorney General Walter Dellinger noting that the Articles Congress permitted Ambassadors Arthur Lee, Benjamin Franklin, and John Jay to keep gifts from foreign monarchs) (link). 
state offices to the operation of the federal government, Teachout's historical claim in regard to the Framers' purported "obsession" seems misplaced. And if her historical claim is incorrect, her larger interpretive claim is thrown into substantial doubt. Because the scope of the Foreign Emoluments Clause is limited to Offices... under [the United States], and excludes offices under any State, it would seem to follow that if there is a structural anti-corruption principle of constitutional dimension, the scope of that principle-even if "translated" into modern circumstances - cannot reach state election processes.

\section{B. Teachout's Federal Offices Problem}

Additionally, even in regard to federal offices, the Foreign Emoluments Clause remains textually limited to Offices of Profit or Trust under [the United States]. This latter phrase leaves much beyond its scope. It does not encompass:

- United States citizens, even if voting in federal elections or serving on federal juries;

- Attorneys admitted to practice before the bar of a federal court;

- Advisors to the President-even those situated in the White House - who lack individualized legal discretion or power to affect binding legal relations;

- $\quad$ Presidential electors; ${ }^{25}$

\footnotetext{
25 Teachout does not argue that the ACP applies to the presidency because the ACP applies to the processes (elections, etc.) by which electors are chosen, nor does Teachout argue that the Foreign Emoluments Clause directly applies to electors. And for good reason; electors are not officers, and therefore it would seem to follow that they are not officers under the United States. See United States v. Hartwell, 73 U.S. 385, 393 (1867) (Swayne, J.) ("An office is a public station, or employment, conferred by the appointment of government. The term embraces the ideas of tenure, duration, emolument, and duties.") (link). Although the position of elector sometimes carries state-granted emoluments, it lacks federal emoluments, which indicates that it is not an office of or under the United States. See id.; $c f$. Satrucharla Chandrasekhar Raju v. Vyricherla Pradeep Kumar Dev, A.I.R. 1992 S.C. 1959, para. 7 (India) (Reddy, J.) (explaining that in determining whether a position is an office of profit under the government of India, the court examines, among other factors, if the post is "paid out of the revenues of [the] Government of India") (link). Nor are electors officers of the United States (albeit, a potentially narrower category than officers under the United States). See In re Green, 134 U.S. 377, 379 (1890) (Gray, J.) ("Although the electors are appointed and act under and pursuant to the Constitution of the United States, they are no more officers or agents of the United States than are the members of the state legislatures when acting as electors of federal senators, or the people of the States when acting as electors of representatives in Congress.”) (link); see also McPherson v. Blacker, 146 U.S. 1, 35 (1892) (Fuller, C.J.) (quoting In re Green approvingly) (link); Vasan Kesavan, The Very Faithless Elector?, 104 W. VA. L. REV. 123 passim (2001) (suggesting that electors are properly characterized as holders of Article VI
} 


\section{NORTHWESTERN UNIVERSITY LAW REVIEW COLLOQUY}

- State judges in their official capacity subject to mandamus orders or other direction by the federal courts;

- $\quad$ Elected territorial officials;

- Territorial officers appointed by elected non-judicial territorial officials;

- $\quad$ Enlisted federal (or state) military personnel;

- $\quad$ State militia officers, even when called into national service by the President during an insurrection or other national emergency;

- $\quad$ Permanent or ad hoc federal civil servants;

- $\quad$ Federal contractors;

- National (or state) convention members under Article V;

- American nominees or appointees to treaty-created offices; ${ }^{26}$

- Multi-state compact officials;

- Qui tam plaintiffs asserting a federal cause of action;

- Holders of letters of marque and reprisal;

- Trustees, directors, members, officers, employees, and other agents of federally chartered trusts, corporations, and other private entities with legal personality; and,

- Individuals affiliated with private entities created under state (or federal, or even foreign) law in which

public trusts under the United States, and are neither state officers, nor officers under the United States); infra note 27.

26 See infra note 50 (discussing John Randolph's position). 
significant equity (or, possibly, debt) is held by the United States government. ${ }^{27}$

The Foreign Emoluments Clause's inapplicability to these positions challenges Teachout's "obsession” claim.

\section{Teachout's Federal Impeachment and Disqualification Problem}

Similarly, a corrupt (elected or appointed) federal official who is impeached by the House, tried, convicted, and disqualified by the Senate remains free to take any state office, and according to the academic consensus also remains free to hold a seat in Congress. ${ }^{28}$ In other words, if the Framers believed that corruption posed the chief danger to the new Republic, one wonders why corrupt Senate-convicted and disqualified former federal officials were still eligible to hold state offices - offices which could indirectly affect significant operations of the new national government - and were also (arguably) eligible to hold congressional seats, thereby injecting corrupt

27 Although the various posts listed in the main text are not Offices of Profit or Trust under [the United States], as used in the Foreign Emoluments Clause, some (but not all) of these posts are Offices of Authority under the United States, as used in the Ineligibility Clause. See supra note 22. In any event, the argument I put forward in the main text remains sound if the reader agrees that any one of these listed positions is beyond the scope of the Foreign Emoluments Clause (and related constitutional provisions also using Office... under the United States language). As I explain in more detail below, Office ... under [the United States], as used in the Foreign Emoluments Clause, extends to public offices created or defeasible by federal statute. It includes officers of the United States subject to the Appointments Clause, Inferior Office Appointments Clause, and Recess Appointments Clause, and it also includes non-member legislative officers chosen under the House Officers Clause and Senate Officers Clause. Elected (state and federal) officials do not fall within its scope. But see Akhil Reed Amar, Philadelphia Revisited: Amending the Constitution Outside Article V, 55 U. CHI. L. REv. 1043, 1061 n.67 (1988) ("[I]t should be noted that if [Article V] delegates [to a national convention] can be considered 'officers of the United States' - and it is not implausible to view them as such") (link). Amar puts forward no argument supporting his puzzling position. Full support for my claim in regard to each of the positions listed in the main text of this Essay can be found in my other publications and working papers. See, e.g., Seth Barrett Tillman, Interpreting Precise Constitutional Text: The Argument for a "New" Interpretation of the Incompatibility Clause, the Removal \& Disqualification Clause, and the Religious Test Clause-A Response to Professor Josh Chafetz's Impeachment \& Assassination, 60 CLEVELAND ST. L. REV. (forthcoming circa Sept. 2012) (manuscript passim) (link); cf., e.g., United States v. Mouat, 124 U.S. 303, 307 (1888) (Miller, J.) ("Unless a person in the service of the Government, therefore, holds his place by virtue of an appointment by the President, or of one of the courts of justice or heads of Departments authorized by law to make such an appointment, he is not strictly speaking, an officer of the United States." (emphasis added)) (link).

28 See U.S. CONST. art. I, § 2, cl. 5 (House Impeachment Clause); U.S. CONST. art. I, § 3, cl. 6 (Senate Trial Clause); U.S. CONST. art. I, $\S 3$, cl. 7 (Removal and Disqualification Clause); U.S. ConST. art. II, § 4 (Impeachment Clause) (link); Akhil Reed Amar \& Vikram David Amar, Is the Presidential Succession Law Constitutional?, 48 STAN. L. REV. 113, 115 n.14 (1995) (asserting that a disqualified federal official may subsequently hold a seat in Congress). This position is representative of the modern academic consensus; indeed, the origin of that consensus goes back to this influential Stanford Law Review publication. See id. 
officials directly into national policy-making. This too seems to challenge Teachout's "obsession" claim.

\section{Teachout's Foreign Law Problem}

Likewise, the Foreign Emoluments Clause proscribes a holder of an Office ... under [the United States] from "accepting" a foreign government's gift or title of nobility. That restriction would not apply either to a person who accepts a foreign government's gift or title prior-even, perhaps, just prior - to becoming a federal officer, or to a person who accepts a foreign government's gift or title after leaving federal office. Likewise, that restriction would not apply to an active federal officer who receives a foreign government's gift or title by operation of foreign law-e.g., inheritance - absent any voluntary or individualized act of "acceptance." 29 If the world of the Framers was corruption-obsessed, as argued by Teachout, then why does the Framers' Foreign Emoluments Clause not direct federal officers receiving foreign offices or titles via inheritance to actively reject such benefits (or that failure to do so will result in the loss of domestic office)?

Again, if the Framers had been "obsessed" with corruption, it is difficult to understand why state offices (and thereby state election processes) and all of these federal positions and possibilities (e.g., continued government service after disqualification for corruption and inheritance under foreign law) were left beyond the scope of the Foreign Emoluments Clause. Was not inheritance the dominant way foreign titles were transmitted in the eighteenth century? Would inheritance of titles have been beyond the imagination of the Framers in a corruption-obsessed world?

\section{E. Teachout's Independent Expenditures Problem}

The Foreign Emoluments Clause's use of “accept" would seem to put independent campaign contributions and expenditures involving federal and state elections (initiatives, and referenda ${ }^{30}$ ) beyond the scope of Teachout's ACP. Where election funds are raised and spent independently of candidates (including incumbent candidates), where such monies do not flow through candidates' hands (or their agents' hands), and where the candidates do not direct how the money is spent, the monies will be spent without any meaningful or substantive "acceptance" by the candidates.

${ }^{29}$ I thank Luke Beck for this insight. See generally Sykes v Cleary (1992) 176 CLR 77, 113 (Austl.) (Brennan, J) (discussing the extent of the constitutional disqualification against holding domestic public office when foreign citizenship accrues by operation of foreign law absent any positive act by the recipient).

${ }^{30}$ Constitutional, statutory, and municipal initiatives and referenda generally lack incumbents and candidates. Thus, there is no "Officer . . under [the United States]" to "accept" the benefit conferred. Likewise, efforts to promote or to stop proposals to amend the Constitution - among both the public and elected officials - would seem to lack incumbents capable of "accepting" any benefit. See generally U.S. CONST. art. V (discussing formal procedural requirements for amending the Constitution) (link). 
It would seem to follow that in regard to all federal and state elected positions (i.e., the President, Vice President, federal electors, members of Congress, and all elected state posts), the Foreign Emoluments Clause cannot provide a textual basis (even if "translated" into modern circumstances) for regulating independent campaign contributions and expenditures. The contrary view would seem to denude "accept" of any substantial meaning. In short, if Teachout is to argue that independent expenditures may be validly regulated by federal statute under the aegis of her free-standing anticorruption principle, then she must do so without relying on the Foreign Emoluments Clause.

\section{F. Teachout's Original Intent Problem(s)}

The logic of Teachout's original intent-based argument would expand the scope of the ACP based on the Framers' general views or corruptionspeak as expressed in their debates at the Federal Convention and in the state ratifying conventions. But the plain text of the Foreign Emoluments Clause-i.e., the Constitution's original public meaning-blocks going down that road. The Foreign Emoluments Clause has no application absent: (i) an acceptance of a present, title, etc. by (ii) an Office $[r]$. . under [the United States]. Try as you like, one cannot squeeze everything into the scope of those two textual limitations.

Indeed, Teachout's The Anti-Corruption Principle might supply the textbook example of the danger of the original intent approach to constitutional interpretation. The democratically enacted public text of the Constitution recedes, only to be replaced by amorphous normative principles whose contours are "discovered" in documents that were not widely-or even publicly-available during the ratification process. If those normative principles have deep support in the present day, they might have some strong claim on the modern interpreter. But a generalized fear that the other is corrupt or disloyal seems an odd and, perhaps, a dangerous place to begin our long march back to the lost world of 1787.

No doubt America has had and continues to have enemies abroad and traitors at home. Benedict Arnold was real. But America's history also illustrates that some fears and claims involving divided loyalties have been, at times, exaggerated and misused. We might contemplate carefully before treading down this road; it might lead to places we had best avoid. ${ }^{31}$

31 See Teachout, supra note 8, at 177 ("Much like one can talk freely about partition in Ethiopia/Eritrea but not in Israel/Palestine, one can talk freely about the limits of other constitutionally protected rights, but [one] must be more cautious around First Amendment ones." (emphasis added)). Precisely what does Professor Teachout think will happen to Americans who speak or write incautiously in regard to the limits of First Amendment rights, that is, other than finding themselves published in Cornell Law Review (or in a subsequent exchange on Northwestern University Law Review Colloquy)? See also Zephyr Teachout, Extraterritorial Electioneering and the Globalization of American Elections, 27 BERKELEY J. INT'L L. 161, 188 (2009) (“Although [Rupert Murdoch] took the oath of [United 


\section{NORTHWESTERN UNIVERSITY LAW REVIEW COLLOQUY}

\section{THE ANTI-CORRUPTION PRINCIPLE EXTENDS ONLY TO APPOINTED FEDERAL OFFICES, NOT TO ELECTED FEDERAL POSITIONS}

Throughout The Anti-Corruption Principle, Teachout assumes that the Foreign Emoluments Clause's Office ... under [the United States] language applies to members of Congress ${ }^{32}$ and the presidency ${ }^{33}$ (and, apparently, to the vice presidency). She offers no support, evidence, or argument for this position. There are good textual and historical reasons to believe she is incorrect about her assumption, and if she is incorrect then her ACP applies to no state or federal elected positions. None. In other words, even if the ACP exists, it has a very limited scope, and has no implications for election law or First Amendment jurisprudence.

To be clear, Teachout's position is not frivolous. The meaning of $O f$ fice of Profit or Trust under [the United States] has not been conclusively settled by the courts or by scholarship. And, there are several modern commentators who take the same position or one akin to hers. ${ }^{34}$ There may also

States] citizenship, he has given no indication that this oath changed his perspectives on obligations of the news reporting agency that he runs.") (link). Is not this a bit of "heads I win, tails you lose"? Murdoch, according to Teachout, is somehow blameworthy because he failed to allow his new national loyalties to affect his business judgment. But corporations are essentially "foreign," according to Teachout, precisely because their "legal loyalties necessarily exclude patriotism." Teachout, supra note 1, at 393 n.245 (emphasis added). If Teachout's latter claim is true, then Murdoch was in no position to express his new national loyalties in the corporate context. If not true, then Teachout's Foreign Emoluments Clause-driven analysis has no useful application to corporations and other similar business entities.

32 See, e.g., Teachout, supra note 1, at 354 ("[T] he limits on holding multiple offices, the limitations on accepting foreign gifts ... were all considered in light of concerns about corruption, and designed to limit legislators' opportunities to serve themselves." (emphasis added)); id. at 361-62; see also, e.g., Teachout, supra note 31, at 168-69 ("Article I, Section 9, Clause 8 of the U.S. Constitution was written to eliminate the threat of foreign money corrupting our domestic decisions [made by federal officials]."). Teachout is hardly alone in this regard. See, e.g., RAOUL BERGER, IMPEACHMENT: THE CONSTITUTIONAL PROBLEMS 226 n.11 (1974) (arguing that the Foreign Emoluments Clause applies to Senators). But see, e.g., infra notes 39-41 (collecting contrary authority).

33 See, e.g., Teachout, supra note 1, at 366 ("Foreign corruption of the Executive was a concern as well, as we saw in the Foreign Gifts Clause. The Framers gave the Executive the treaty-making power after much disturbed debate." (emphasis added) (footnote omitted)). Again, Teachout is hardly alone in this regard. See, e.g., AKHIL REED AMAR, AMERICA's CONSTITUTION: A BIOGRAPHY 182 (2005) (" $[\mathrm{T}]$ he ... general language of Article I, section 9 barred all federal officers, from the president on down, from accepting any 'present' or 'Emolument' of 'any kind whatever' from a foreign government without special congressional consent." (emphasis added)). But see, e.g., infra notes 39-41 (collecting contrary authority).

34 See, e.g., Applicability of the Emoluments Clause and the Foreign Gifts and Decorations Act to the President's Receipt of the Nobel Peace Prize, O.L.C., 2009 WL 6365082, at *4 (2009) (prelim. print) (Acting Assistant Attorney General David J. Barron announcing in ipse dixit that " $\mathrm{t}] \mathrm{h}$ he President surely 'hold[s] an[] Office of Profit or Trust' ...." (quoting U.S. CONST. art. I, § 9, cl. 8)) (link); see also, e.g., Steven G. Calabresi, Closing Statement, A Term of Art or the Artful Reading of Terms?, in Seth Barrett Tillman \& Steven G. Calabresi, Debate, The Great Divorce: The Current Understanding of Separation of Powers and the Original Meaning of the Incompatibility Clause, $157 \mathrm{U}$. PA. L. REV. PENNumBRA 134, 159 (2008) [hereinafter The Great Divorce] ("The text forbids members of Congress from holding 'any Office under the United States.' The presidency is plainly such an office.”) (link); Richard D. Friedman, Some Modest Proposals on the Vice-Presidency, 86 MicH. L. REV. 1703, 1720 
have been some founding era material supporting her position. But, the dominant view among the Framers and the prevailing public meaning at the time of ratification - as indicated by the Constitution's text and contemporaneous practice-appears to have been otherwise. Office... under [the United States] as used in the Foreign Emoluments Clause and other constitutional provisions extends to appointed offices, i.e., offices created or defeasible by federal statute, not elected positions.

There are several good reasons to believe that Office of Profit or Trust under [the United States], as used in the Foreign Emoluments Clause, does not reach federal elected positions, i.e., members of Congress, the presidency, and the vice-presidency. First, eighteenth-century British statutespredating the Constitution-made use of the phrase office under the Crown. ${ }^{35}$ The two phrases are clearly akin, and the latter did not extend to members of Parliament or to other elected positions. ${ }^{36}$ Second, state constitutions and state statutes frequently make use of the phrase Office ... under this State. State court jurisprudence discussing the meaning of Office... under this State is not uniform. There is, however, a line of case law excluding constitutionally-created elective office from the scope of Office under this State. ${ }^{37}$ Third, the text of the Constitution would seem to distinguish

n.72 (1988) (arguing that the vice presidency is an "office ... under the United States"); Roderick M. Hills, Jr., A Defense of State Constitutional Limits on Federal Congressional Terms, 53 U. PITT. L. REV. 97, 113 n.59 (1991) (describing "congressional seats" as "offices of trust or profit" under the United States); John F. Manning, Response, Not Proved: Some Lingering Questions About Legislative Succession to the Presidency, 48 STAN. L. REV. 141, 146 (1995) (asserting, without analysis, that "[t]he Presidency is surely an 'Office under the United States"'); Michael Stokes Paulsen, The Constitutional Power to Interpret International Law, 118 YALE L.J. 1762, 1772 (2009) (implying that the President falls under the scope of the Foreign Emoluments Clause) (link); Saikrishna Bangalore Prakash, Why the Incompatibility Clause Applies to the Office of President, 4 DuKE J. CONST. L. \& PUB. POL'Y 143, 143 (2009) (asserting that "[t]he President occupies an 'Office under the United States"' and denominating that position the "conventional wisdom") (link); Paul R. Verkuil, Separation of Powers, the Rule of Law and the Idea of Independence, 30 WM. \& MARY L. REV. 301, 310 \& n.45 (1989) (assuming the Foreign Emoluments Clause applies to members of Congress) (link); supra notes 32-33 (collecting authority); cf., e.g., Josh Chafetz, 20th Amendment Trivia, CONLAWPRoF (Nov. 10, 2008), http://tinyurl.com/2ajsxxe ("I happen to think that the President is an officer under the United States, but some think otherwise.") (link).

35 See, e.g., Succession to the Crown Act, 6 Ann., c. 7, § 25 (1707) (Gr. Brit.) (using "office of place or profit whatsoever under the Crown" (emphasis added)) (link).

36 See, e.g., AnNe Twomey, The Constitution of New South WAles 438 (2004) ("As it is an elective office, and not generally subject to the direction or supervision of the government, one would assume that it is not an office held 'under the Crown'.") (link).

37 See, e.g., State ex rel. Ragsdale v. Walker, 33 S.W. 813, 814 (Mo. 1896) (Macfarlane, J.) (“An office under the state must be one created by the laws of the state. The incumbent must be governed by state laws, and must exercise his powers and perform his duties in obedience to a statute." (emphasis added)); see also, e.g., Britton v. Steber, 62 Mo. 370, 374 (1876) (per curiam) ("A State officer may be connected with some of the municipal functions, but he must derive his powers from a State statute and execute his powers in obedience to a State law." (emphasis added)). Constitutional positions such as governor or member of the state legislature would appear to be beyond the scope of office under the state (as understood by the Missouri courts). But cf., e.g., Willis v. Potts, 377 S.W.2d 622, 628 
Office ... under the United States from members of Congress. For example, the Elector Incompatibility Clause provides: "[N]o Senator or Representative, or Person holding an Office ... under the United States, shall be appointed an Elector." ${ }^{38}$ Arguably, the language of the Elector Incompatibility Clause would seem to distinguish Office... under the United States from senator and representative positions; otherwise the provision's language is needlessly redundant. A fair reading of the Incompatibility Clause also leads to the same conclusion: the constitutional text distinguishes $O f$ fice under the United States from members of Congress. ${ }^{39}$ Finallyalthough this conclusion is somewhat counterintuitive to modern scholarsearlier commentators recognized that the presidency was not within the ambit of the phrase Office... under the United States. As nineteenth-century commentator David A. McKnight put it: "It is obvious that ... the President is not regarded as 'an officer of, or under, the United States,' but as one branch of 'the Government." "40 Indeed, McKnight's position appears to be rooted in the text of the Constitution's Necessary and Proper Clause, which distinguishes "departments" from "officers."

(Tex. 1964) (Hamilton, J., dissenting) ("Without exception every jurisdiction has declared a municipal office not to be an office under the state unless it is one created by the Constitution or statutes, its powers and duties [are] defined by statute, or [it is] an office created by some other authority such as a municipality, but upon which there is imposed by statute certain state duties." (emphasis added)) (link).

38 U.S. CONST. art. II, § 1, cl. 2 (emphasis added) (link).

39 See supra note 21; William Bennett Munro, The Government of the United States: NATIONAL, STATE, AND LOCAL 297 (5th ed. 1946) ("The phraseology [of the Incompatibility Clause and Elector Incompatibility Clause] suggests that appointment, as against election, is the essential mark of 'civil office' or even 'office."') (link). It is possible that Justice Story was the first commentator to note the distinction between elected officials and appointed officers. See 2 JOSEPH STORY, COMMENTARIES ON THE CONSTITUTION OF THE UNITED STATES $\$ 791$, at 260 (photo. reprint 1999) (Boston, Hilliard, Gray, \& Co. 1833) ("[The Impeachment Clause] says, 'the president, vice-president, and all civil officers (not all other civil officers) shall be removed,' \&c. The language of the clause, therefore, would rather lead to the conclusion, that the[] [President and Vice President] were enumerated, as contradistinguished from, rather than as included in the description of, civil officers of the United States." (emphasis added)) (link); see also Ruth C. Silva, Presidential SuCCESSION 149 (1951) ("“'Officers of the United States' are not appointed by electoral colleges. They are appointed by the President and Senate, by the President alone, by the department heads, or by the courts of law.") (link).

40 See David A. McKnight, The Electoral System of the United States 346 (Philadelphia, J.B. Lippincott \& Co. 1878) (emphasis added). McKnight was hardly alone. See infra note 51 (distinguishing office from public trust); see also CONGRESSIONAL RECORD: CONTAINING THE PROCEEDINGS OF THE SENATE SitTing FOR THE TRIAL OF William W. BELKNAP, LATE SECRETARY OF WAR, ON THE ARTICLES OF IMPEACHMENT EXHIBITED BY THE HOUSE OF REPRESENTATIVES 145 (Washington, Government Printing Office 1876) (Senator Newton Booth, from California, stating, on May 27, 1876, "[T]he President is not an officer of the United States. As was tersely said by ... Senator [Boutwell] from Massachusetts, . . 'He is part of the Government." (citing STORY, supra, note 39, § 791)) (link).

41 Compare, e.g., U.S. CONST. art. I, § 8, cl. 18 (distinguishing "department[s]" from "officer[s]" in the Necessary and Proper Clause) (link), with Suspension of the Privilege of the Writ of Habeas Corpus, 10 Op. Att'y Gen. 74, 79 (1861) (Bates, Att'y Gen.) ("The President is a department of the government; and ... the only department which consists of a single man ...." (emphasis added)). Bates eschews describing the President in the language of office and officer. 
Still, I do not suggest that the Constitution's text, drafting history, and ratification debates are free from all ambiguity on the meaning of Office... under the United States. Fortunately, we can turn to two incidents from President George Washington's first administration to understand the meaning of this somewhat opaque phrase. Traditionally, precedents set by the Washington administration have carried great weight in originalist analysis both left and right of center, in part because Washington was sensitive to the weight that future generations would accord his actions and also because active partisan politics had not yet begun. ${ }^{42}$

\section{A. Alexander Hamilton's Response to a Senate Order}

On May 7, 1792, the Senate issued a (purported) order directing the Secretary of the Treasury, Alexander Hamilton, to prepare a financial statement as follows:

That the Secretary of the Treasury lay before the Senate, at the next session of Congress, a statement of the salaries, fees, and emoluments, for one year, ending the first day of October next, to be stated quarterly, of every person holding any civil office or employment under the United States, (except the judges,) together with the actual disbursements and expenses in the discharge of their respective offices and employments for the same period . . . . ${ }^{43}$

In other words, Hamilton was sent an official request for information by the Senate of the United States.

Hamilton responded the following February:

[Philadelphia, February 26, 1793

Communicated on February 27, 1793]

[To the President of the Senate]

The Secretary of the Treasury, in obedience to the order of the Senate of the 7th of May last, respectfully transmits herewith sundry statements of the Salaries fees and Emoluments for one Year ending the first of October 1792, of the Persons holding civil offices or employments under the

\footnotetext{
42 See Letter from George Washington to James Madison (May 5, 1789), in 30 THE WRITINGS OF GEORGE WASHINGTON 310, 310-11 (John C. Fitzpatrick ed., 1939) ("As the first of every thing, in our situation will serve to establish a Precedent, it is devoutly wished on my part, that these precedents may be fixed on true principles." (emphasis in the original)); AMAR, supra note 33, at 470; Steven G. Calabresi \& Saikrishna B. Prakash, The President's Power to Execute the Laws, 104 YALE L.J. 541, 642 n.450 (1994) (quoting Washington to Madison correspondence, supra) (link).

431 Journal of the SENATE of THE United StAtes of AMERICA 441 (Washington, Gales \& Seaton 1820) (May 7, 1792 entry) (italics added and bold added) (link).
} 


\section{NORTHWESTERN UNIVERSITY LAW REVIEW COLLOQUY}

$[U]$ nited States (except the Judges) as far as Returns have been rendered - together with the disbursements and Expences in the discharge of their respective offices and employments for the same Period.

$\begin{array}{ll}\text { No I. } & \text { relating to the Department of State .... } \\ \text { No. II } & \text { Treasury Department .... } \\ \text { No III } & \text { Department of war }\end{array}$

$\begin{array}{ll}\text { No VI } & \text { Office of the Secretary of the Senate } \\ \text { No VII } & \text { Ditto Clerk of the House of Representa- } \\ \text { tives }\end{array}$

No XII Clerks of the District Courts

…

No XVIII Keepers of Lighthouses

All which is humbly submitted

$\begin{array}{ll}\text { Tlexander Hamilton } \\ \text { Treasury Department } & \begin{array}{l}\text { Alecy of the Treasury } \\ \text { February } 261793^{44}\end{array}\end{array}$

Hamilton was instructed to include "every person holding any civil office or employment under the United States, (except the judges)." Every, not some; any, not some. ${ }^{45}$ The Senate's use of "except the judges" provided no excuse to fail to list anyone other than judges from his reply. His reply matched the language of the Senate order: listing "civil offices or employments under the [U]nited States (except the Judges)."

What did Hamilton do? His reply to the Senate was roughly ninety handwritten manuscript pages, and did not include the salaries or disbursements made to senators or representatives. Likewise, Hamilton's reply did not include line entries for the President and Vice President. On the other hand, Hamilton's reply did include line entries for the salary and expenses of the Secretary of the Senate and his staff, and for the salary and expenses of the Clerk of the House and his staff.

44 AleXANDER Hamilton, Report on the Salaries, Fees, and Emoluments of Persons Holding Civil Office Under the United States (Feb. 26, 1793), in 14 THE PAPERS OF ALEXANDER HAMILTON 157, 15759 (Harold C. Syrett \& Jacob E. Cooke eds., 1969) (editors' footnotes omitted) (emphasis added).

${ }^{45}$ Cf. Steven G. Calabresi, Rebuttal, Does the Incompatibility Clause Apply to the President?, in The Great Divorce, supra note 34, at 141 ("The word 'any' means 'any,' not 'some of."'); Vasan Kesavan, Is the Electoral Count Act Unconstitutional?, 80 N.C. L. REV. 1653, 1792 (2002) ("The word 'every' ... means every and not some.") (link). 
Simply put, Hamilton's reply included all appointed officers from each of the three branches of the federal government, but no elected officials from any branch. Again, if Hamilton was correct, if he correctly identified the scope of Office ... under the United States, and usage here was uniform and followed the Constitution's usage, then Teachout's ACP cannot reach any federal elected officials.

\section{B. George Washington's French Gifts}

On December 22, 1791, the French ambassador to the United States, Jean-Baptiste, chevalier de Ternant, sent President George Washington a letter stating: "Permit me to present you with a new print of the king of the french-I shall feel a very great Satisfaction if you will consider that feeble mark of my lively and respectful attachment for your person, as worthy your kind acceptance." 46

President Washington replied the same day. He wrote:

Philadelphia Decr 22nd 1791.

Dear Sir,

I accept, with great pleasure, the new and elegant print of the King of the French, which you have been so obliging as to send to me this morning as a mark of your attachment to my person. You will believe me, Sir, when I assure you, that I have a grateful and lively sense of the personal respect and friendship expressed in your favor which accompanied the Print, and that I am, with sentiments of sincere esteem and regard, Dear Sir, your most obedt Servt

Go: Washington. ${ }^{47}$

Washington accepted the ambassador's gift (the print and its frame), he kept the gift, and he never asked for congressional consent to accept or to keep the gift. This gift was not one of de minimis value, ${ }^{48}$ nor was it a gift

${ }^{46}$ Letter from Ambassador Ternant to George Washington (Dec. 22, 1791), in 9 THE PAPERS OF GeORGE WASHington 306, 306 n.1 (Mark A. Mastromarino \& Jack D. Warren, Jr., eds., 2000) (emphasis added). Washington received other foreign gifts. While President, LaFayette, then a French government official, gave Washington the key to the Bastille. See Seth Barrett Tillman, Opening Statement, Why President-Elect Obama May Keep His Senate Seat After Assuming the Presidency, in The Great Divorce, supra note 34, at 138-40. Although Washington accepted and kept the key, he failed to ask for congressional consent to do so. Id.; see also supra note 12. It is also possible that, on another occasion, Louis XVI gave Washington a carpet. See 2 Esther Singleton, THE Furniture OF OUR Forefathers 503 (N.Y., Doubleday, Page \& Co. 1906) (link). If and when this happened is unclear.

47 See Letter from George Washington to Ambassador Ternant (Dec. 22, 1791), in 9 THE PAPERS OF GEORGE WASHINGTON, supra note 46, at 306 (emphasis added).

48 See William Adair, George Washington's Frames: A Study in Contrasts, PICTURE Framing Magazine, June 1992, at 34, 34-35; Wendy Wick Reaves, The Prints, AnTiQues, Feb. 1989, at 502, 502-03; Louis Seize, Roi de Français, Restaurateur de la Liberté, 1790, GEORGE WASHINGTON's 


\section{NORTHWESTERN UNIVERSITY LAW REVIEW COLLOQUY}

from a close personal friend or relative of Washington's. It was an official or diplomatic gift from a foreign ambassador to our head of state. ${ }^{49}$ How can Teachout's ACP-framework explain Washington's conduct? Will Teachout suggest that Washington was corrupt?

I suggest that there is a very simple way to account for Washington's conduct. Washington acted correctly; it is Teachout's corruption-centered Foreign Emoluments Clause analysis which errs. President Washington was not an Officer... under the United States, and he did not conceive of his position as one. Therefore, he did not fall under the aegis of the Foreign Emoluments Clause. You might very well ask: if Presidents are not Officers ... under the United States, then what are they $?^{50}$ They are magistrates or holders of public trusts under the United States per Article VI. ${ }^{51}$

MOUNT VERNON: ESTATE, MUSEUM \& GARDENS, http://emuseum.mountvernon.org/code/emuseum.asp (last visited Jan. 17, 2012) (link).

49 See William B. Adair, A Masterpiece of Artisanship, Picture Framing Magazine, Aug. 2010, at 28, 28 (describing the print and frame as "an official diplomatic gift") (link); id. at 32 ("The history of this Royal Palace frame is clear, having been an official gift to Washington."); cf. Gifts of State, NATIONAL ARChIVES, http://tinyurl.com/7nk9cvs (last visited Mar. 4, 2012) (“[I]ndeed, every President since George Washington has received gifts of state.") (link).

50 Cf. Amar \& Amar, supra note 28, at 137 n.143 ("If an acting President, wielding the full and awesome executive power of the United States, is not an 'Officer of the United States,' what is he?'). Unfortunately, this confusion is hardly unique. See, e.g., Oliver P. Field, The Vice-Presidency of the United States, 56 AM. L. REV. 365, 382 (1922) ("Whether the president and vice-president are officers of the United States is a subject on which conflicting opinions are held. It is not possible to deal here at length with ... that question ...." (footnote omitted)); cf., e.g., 3 ANNALS OF CONGRESS 281 (Washington, Gales \& Seaton 1849) (Dec. 1791) (Congressman Gerry: "[I]f [the Speaker] is not an officer [for Succession Clause purposes], what is he?") (link); 29 ANNALS OF CONGRESS 947 (Washington, Gales \& Seaton 1854) (Feb. 1816) (quoting John Randolph of Roanoke's asking rhetorically "[i]f the appointment in question [to a treaty-created office] be not an office, he said he should like to know what an office is.") (link).

51 See supra note 41 (distinguishing office from department); cf. supra notes 39-40. Compare U.S. CONST. art. VI, $\S 3$ ("[N]o religious Test shall ever be required as a Qualification to any Office or public Trust under the United States.” (emphasis added)) (link), with THE FEDERALIST No. 70, supra note 17, at 424 (Alexander Hamilton) ("If it be a public trust or office, in which they are clothed with equal dignity and authority, there is peculiar danger of personal emulation and even animosity." (emphasis added)) (link). Similar language also appears in post-ratification materials. See, e.g., Letter from George Washington to Eléonor François Élie, Comte de Moustier (May 25, 1789), in 30 THE WRITINGS OF GEORGE WASHINGTON, supra note 42, at 334 ("The impossibility that one man should be able to perform all the great business of State, I take to have been the reason for instituting the great Departments, and appointing officers therein, to assist the supreme Magistrate in discharging the duties of his trust." (emphasis added)); see also Free Enter. Fund v. Pub. Co. Accounting Oversight Bd., 130 S. Ct. 3138, 3146 (2010) (Roberts, C.J.) (quoting from the same passage of the Washington-to-Élie letter) (link); AMAR, supra note 33, at 193 (same); Calabresi \& Prakash, supra note 42, at 637 (same); cf. 9 STATE OF New YorK: Messages From the Governors, 1892-1898, at 515 (Charles Z. Lincoln ed., Albany, J.B. Lyon Co. 1909) (reproducing the May 23, 1894 veto message of Governor Roswell P. Flower that placed the officers below the holders of public trusts by stating: "That one who holds the power to appoint a public officer, to remove him at will and appoint his successor, to fix his salary and to change it from time to time, holds a public trust will not be disputed ...." (emphasis added)) (link). 
If Washington correctly identified the scope of Office... under [the United States], as used in the Foreign Emoluments Clause, then Teachout's ACP has no application to presidents or presidential election processes.

\section{TEACHOUT'S ANTI-CORRUPTION PRINCIPLE IS A PRIVATE LAW PRINCIPLE GRAFTED ONTO OUR PUBLIC LAW}

If the Hamilton and Washington evidence, along with the other evidence and arguments presented, establish that the President, Vice President, federal electors, members of Congress, and state officers are beyond the scope of Office ... under [the United States] as used in the Foreign Emoluments Clause, then it would seem to follow that these positions are also beyond the scope of the Office ... under the United States language (or the roughly comparable language) in the Incompatibility Clause and the Ineligibility Clause. ${ }^{52}$ Teachout primarily relied upon these three provisions in The Anti-Corruption Principle. If all elected state and federal offices are excluded from the Foreign Emoluments Clause's operation, and they are also excluded from the Office... under the United States language in the other two clauses, it makes no sense to suggest that the Framers were "obsessed" with corruption. Likewise, if all elected state and federal offices are excluded from the Foreign Emoluments Clause's operation and are also excluded from the Office... under the United States language in the other two clauses, it makes little sense to suggest that, if you put all these provisions together, then, voilà, you have a free-standing structural doctrine or principle establishing a congressional power to regulate elections or election-related contributions and spending.

My view is that the Washington and Hamilton evidence goes far in establishing that the original public meaning of the Office... under [the United States] language in the Foreign Emoluments Clause does not extend to elected positions. Whether this particular issue remains in dispute between Professor Teachout and me is unclear. Before burdening the reader

\footnotetext{
52 See supra notes 22, 27 (opining on the scope of Office under the Authority of the United States, as used exclusively in the Ineligibility Clause, and noting that this expression has a wider scope than the more generic Office ... under [the United States] language used in the Foreign Emoluments Clause and in other constitutional provisions). Of course, I am assuming that Office . . under the United States (except for Office under the Authority of the United States) was a term of art, used identically across constitutional provisions. Id. But see David P. Currie, The Constitution in Congress: The Second Congress, 1791-1793, 90 Nw. U. L. REV. 606, 624-25 (1996) ("[I]t is difficult to say that the Constitution adopts a single meaning of the term 'office' or 'officer'; each clause employing these terms must be interpreted according to its own context, history, and purpose."). If my assumption is correct-and Currie's assumption is incorrect - and if the presidency is excluded from the Office under the United States language in the Incompatibility Clause, then that clause does not preclude joint congressionalpresidential service. In other words, the Incompatibility Clause is strictly an anti-conflicts-of-interest or anti-corruption provision; it is not a separation of powers provision. $C f$. Calabresi \& Larsen, supra note 6; Seth Barrett Tillman, Opening Statement, Why President-Elect Obama May Keep His Senate Seat After Assuming the Presidency, in The Great Divorce, supra note 34 passim.
} 
with additional argument and evidence on this point, it might be better to wait and see what Professor Teachout has to say, and if, in light of my critique, she will elaborate further on or reconsider her views regarding the meaning of the Foreign Emoluments Clause and the scope of the ACP.

Additionally, I should like to know how her views cohere (if at all) with those put forward by Professors Akhil R. and Vikram D. Amar, who have argued that the varying terminology in the Constitution relating to office and officer are not meaningfully distinguishable. For example, they have maintained that office of the United States, office under the United States, office under the Authority of the United States, and even Office (standing alone and unmodified) are coextensive and extend exclusively to Executive and Judicial Branch officers (including the President) but exclude elected and appointed legislative officials and officers. ${ }^{53}$ This position is inconsistent with the view Teachout put forward in The Anti-Corruption Principle, and it is also inconsistent with the critique I put forward here. In sum, Teachout's position is that the Constitution's Office... under the United States language embraces all federal elected positions: members of Congress, the presidency, and, apparently, the vice presidency. My view (which relies upon the Hamilton and Washington evidence above) is that all these positions are beyond the scope of the Constitution's Office . . under the United States language. Akhil and Vikram Amar would exclude members of Congress (and non-member legislative officers, such as the Clerk of the House and Secretary of the Senate) from the scope of the Constitution's Office... under the United States language, but they would include the presidency and, apparently, the vice presidency within its scope. The current academic consensus has embraced Akhil and Vikram Amar's position (notwithstanding the position's inconsistency with the Hamilton and Washington evidence and with other early American materials). By contrast, Teachout's position and my own are relative outliers.

This is no mere invitation to engage in a tangential discussion about Akhil and Vikram Amar's scholarship. ${ }^{54}$ Teachout's The Anti-Corruption

\footnotetext{
53 See AMAR, supra note 33, at 182 (“'TT]he ... general language of Article I, section 9 barred all federal officers, from the president on down, from accepting any 'present' or 'Emolument' of 'any kind whatever' from a foreign government without special congressional consent." (emphasis added)); Amar \& Amar, supra note 28, at 114-15 (“As a textual matter, each of these five formulations seemingly describes the same stations (apart from the civil/military distinction) - the modifying terms 'of,' 'under,' and 'under the Authority of' are essentially synonymous."); id. at 115-16 ("Thus, federal legislators are neither 'Officers under the United States,' nor (to the extent that there is any difference) 'Officers of the United States."'); see also Howard M. Wasserman, The Trouble with Shadow Government, 52 EMORY L.J. 281, 288 (2003) (“'Officers of the United States' [and] 'Officers under the United States' [are] synonymous terms which include executive branch officers only.") (link).

54 Admittedly, such a conversation might be difficult, as it appears to me that Akhil Amar's writings on this subject are not entirely internally consistent. See Amar, supra note 27, at 1061 n.67 (asserting that it is "not implausible" to view Article V delegates to a national convention as "officers of the United State"). I see no reasonable way to characterize delegates to an Article V national convention as Judicial Branch or Executive Branch officers. At first blush, their function would appear entirely legislative.
} 
Principle invites us to rewrite First Amendment jurisprudence, but it is also an implicit (or, perhaps, an inadvertent) invitation to rewrite the academic consensus regarding the Constitution's usage in regard to office and officer. Thus, The Anti-Corruption Principle has profound implications for many constitutional provisions, not just the First Amendment. Before we go down that road, Teachout should explain to us exactly what the stakes are and where her new (or purportedly "old" Framer-centric) view will take us. For this reason, it would be desirable, not only for Teachout to respond to my critique, but for other commentators who have taken a position on this issue to do so. ${ }^{55}$

One last point must be made. I do not think the ACP can reach elected positions - state or federal-and, as such, it cannot inform our views of election law or the First Amendment. However, I do agree that Teachout's broad conceptual framework is sound. There is a structural anti-corruption principle of constitutional dimension. That principle, the ACP, vindicates substantial congressional control over statutory officers, i.e., officers under the United States. It puts federal statutory officers in a fiduciary relationship under the government, in respect to the officers' elected masters and all of

However, according to the Amarian framework, the Constitution's officer terminology does not reach the Legislative Branch. So why should the meaning of officers of the United States reach members of a convention with a purely legislative function? Again, since 1995, Akhil Amar has argued in academic fora that statutory legislative officer succession is plainly unconstitutional. See Amar \& Amar, supra note 28 passim. But, in congressional testimony, he took a different position. See Presidential Succession Act: Hearing Before the Subcomm. on the Const. of the H. Comm. on the Judiciary, 108th Cong. 52 (2004) (statement of Akhil Reed Amar) ("And I do think in very, very highly unusual situations where you really try to have Cabinet succession, officer succession, and everyone's gone, I think only a real constitutional zealot, maybe without good judgment, would say you can't have congressional leaders in that circumstance because the Constitution really isn't a suicide pact, and so I think I appreciate sort of the prudence involved there." (emphasis added)) (link). So in precisely what circumstances does the Constitution's use of Office embrace legislative officers? The Presidential Succession Clause uses the language of Officer. Akhil Amar has described former officers as non-officers, i.e., private citizens. As such, he has argued that a Speaker or Senate President pro tem cannot resign his legislative position after succeeding to the presidency. In other words, only current officers are eligible to succeed under the Succession Clause, and if an officer resigns his legislative position after succeeding to the presidency, he loses the ability to retain the presidency. See AmAR, supra note 33, at 171; Amar \& Amar, supra note 28, at 120. However, the Impeachment Clause also uses the language of office, and Professor Amar has suggested that former officers may be impeached. See AMAR, supra note 33, at 568 n.53; Akhil Reed Amar, Attainder and Amendment 2: Romer's Rightness, 95 MicH. L. REV. 203, 214 n.36 (1996) (link). What accounts for these many strange inconsistencies relating to the language of office and officer?

55 Other (living) commentators who have embraced this position that all office-related language means the same thing, or who have taken a position akin to it, include: Professors David Barron, Steven G. Calabresi, Josh Chafetz, Richard D. Friedman, John Manning, Michael Stokes Paulsen, Saikrishna B. Prakash, and Howard M. Wasserman, and Mssrs. John C. Fortier, Vasan Kesavan, Norman J. Ornstein, and David J. Shaw. See, e.g., John C. Fortier \& Norman J. Ornstein, Presidential Succession and Congressional Leaders, 53 CATH. U. L. REV. 993, 995-96 (2004) (“The key term is 'Officer,' by which the Framers likely meant 'Officer of the United States' ... . 'Officers of the United States' are federal executive branch figures.”); supra notes 32-34, and 53 (collecting authority). 
the nation's citizens. In this sense, Teachout's paper is a natural extension of prior scholarship tying our public law to contemporaneous eighteenthcentury private law concepts and doctrine-fiduciary duties, equity jurisprudence, trust law, and corporate law. ${ }^{56}$

For example, Teachout points out that the concept of corruption embraced two related sub-concepts: "dependency" relationships ${ }^{57}$ and "selfserving" activity, i.e., "us[ing] . . public power for private ends." 58 Teachout is entirely correct about this. The domination/dependence theme is the subject matter of the Incompatibility Clause, and the bias/selfdealing/self-serving theme is the subject matter of the Ineligibility Clause. It is precisely because these two clauses attack two different, albeit related, structural problems that the Framers chose different office-laden language within each of these two provisions. The Incompatibility Clause makes use of Office under the United States language, and the Ineligibility Clause makes use of Office under the Authority of the United States language. Different language accomplishes different purposes, just as one might suspect from reasonable and accomplished draftspersons.

Indeed, the distinction between domination by third parties and bias in connection with self-interest still plays an active role in corporate law. A court, applying traditional principles of equity, will review a decision of a board of directors for an alleged breach of the fiduciary duty of loyalty ${ }^{59}$ on a showing that a majority of those voting in support of a contested transac-

56 See infra notes 59-61; supra note 6; Paul Finn, The Forgotten "Trust": The People and the State, in EQUITY: ISSUES AND TRENDS 131, 133 (Malcolm Cope ed., 1995) (noting that English judges brought public officials "into a fiduciary relationship with the public" (citing R. v. Bembridge, (1783) 99 Eng. Rep. 679 (K.B.); 22 St. Tr. 1)) (link); Geoffrey P. Miller, The Corporate Law Background of the Necessary and Proper Clause, in ThE ORIGINS OF THE NECESSARY AND PROPER ClaUSE 144, 144 (Gary Lawson et al. eds., 2010) (link); Ethan J. Leib et al., A Fiduciary Theory of Judging, 101 CALIF. L. REV. (forthcoming 2013), available at http://papers.ssrn.com/abstract_id=2029001 (link); Robert G. Natelson, The Agency Law Origins of the Necessary and Proper Clause, 55 CASE W. RES. L. REV. 243, 285-314 (2004) (link); Robert G. Natelson, The Constitution and the Public Trust, 52 BuFF. L. REV. 1077, 1136-68 (2004) (link); D. Theodore Rave, Politicians as Fiduciaries, 126 HARV. L. REV. (forthcoming Jan. 2013), available at http://papers.ssrn.com/abstract_id=2019159 (link); see also Mary Sarah Bilder, The Corporate Origins of Judicial Review, 116 YALE L.J. 502, 545-55 (2006) (link); Evan J. Criddle, Fiduciary Foundations of Administrative Law, 54 UCLA L. REV. 117, 135-61 (2006) (link).

57 Teachout, supra note 1 , at 363.

58 Teachout, supra note 1, at 373-74.

59 Cf. Memorandum from Randolph D. Moss, Assistant Att'y Gen., Office of Legal Counsel, U.S. Department of Justice, to William P. Marshall, Deputy Counsel to the President, Application of the Coreligionists Exemption in Title VII of the Civil Rights Act (Oct. 12, 2000) (noting that "[t]here is virtually no federal case law discussing what constitutes a 'public trust' for purposes of [A]rticle VI's religious test ban," and hypothesizing that it extends either to "Senators and Representatives" and/or to "any position or function the performance of which is subject to a duty of loyalty to the United States") (on file with the Northwestern University Law Review Colloquy). Notice how Assistant Attorney General Moss makes use of a concept well-developed in private law - the fiduciary duty of loyalty - to understand a public law concept, i.e., the meaning of public trust under the United States. 
tion were either: (i) dominated (lacked independence), or (ii) biased (in the self-serving sense) ${ }^{60}$

I suspect that Teachout's ACP can teach us very little about election law or the First Amendment, but The Anti-Corruption Principle significantly adds to our understanding of the private law genealogy of our Constitution's linguistic heritage. ${ }^{61}$ That might not be what Teachout hoped to achieve, or what Justice Stevens intended in Citizens United, but it is a considerable intellectual accomplishment nonetheless.

${ }^{60}$ See, e.g., In re InfoUSA, Inc. S'holders Litig., 953 A.2d 963, 990 (Del. Ch. 2007) (Chandler, C.) (refusing to dismiss the action under the business judgment rule, and excusing demand on the board because the "complaint contains allegations ... that allow me to determine that a majority of these directors were either interested or lacking in independence at the [relevant] time...." (emphasis added)) (link).

61 The seminal article on the subject is by Dean Enlow. See Eric Enlow, The Corporate Conception of the State and the Origins of Limited Constitutional Government, 6 WASH. U. J.L. \& POL'Y 1 (2001) (link). 